\title{
A Program Based on DAISY Technology to Enhance EFL Student Teachers' Speaking Skills
}

\author{
By \\ Maha Mohamed ElSayed Eid
}

\begin{abstract}
Supervisors
Dr. Ali Abdul Samea Qoura

Professor of Curriculum \& Instruction (TEFL), Faculty of Education, Mansoura University

Dr. Adel Abd Al-Haliem Al-Sheikh

Professor of Curriculum \& Instruction

(TEFL), Faculty of Education, Mansoura

University
\end{abstract}

Journal Of The Faculty Of Education- Mansoura University

No. 111 - July. 2020 


\title{
A Program Based on DAISY Technology to Enhance EFL Student Teachers' Speaking Skills
}

\begin{abstract}
The research aimed to investigate the effectiveness of a program based on DAISY technology in enhancing EFL student teachers' speaking skills. The sample of the study consisted of (34) third-year students at the Faculty of Education, Port Said University. Instruments of the study were speaking skills checklist, speaking scoring rubric, pre and post speaking test, and a program based on DAISY technology. In this study, the one group pre and post-test was used. The results of the study revealed that the study group post-test scores in speaking were significantly better than their pre-test. The study group's gains in these productive skills and the enhancement in their attitude are attributed to using the DAISY technology-based program designed and implemented by the researcher.
\end{abstract}

Key Words: DAISY Technology (Digital Audio Based Information System), Student Teachers, Speaking Skills.

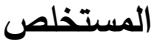

$$
\begin{aligned}
& \text { يقوم البحث الحالي بدراسة تأثير استخدام برنامج قائم علي تكنولوجيا الدعلومات الرقمية الصوتية }
\end{aligned}
$$

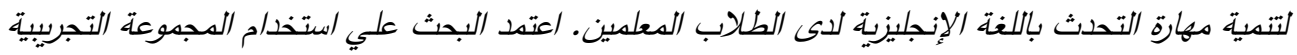

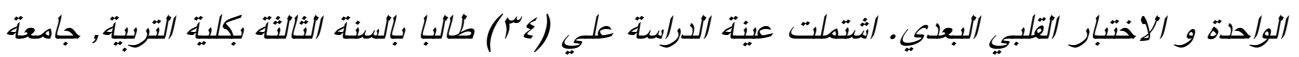

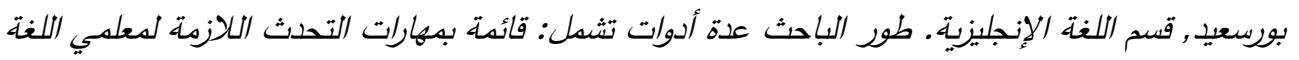

$$
\begin{aligned}
& \text { الانجليزية, ندوذج تقييم أداء الطلاب, اختبار قلبي بعدي, و برنامج قائم علي تكنولوجيا الدعلومات الرقدية }
\end{aligned}
$$

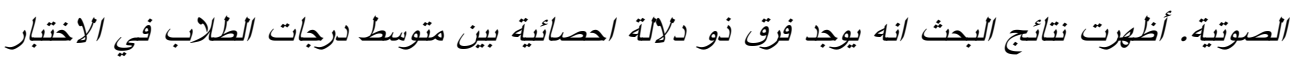

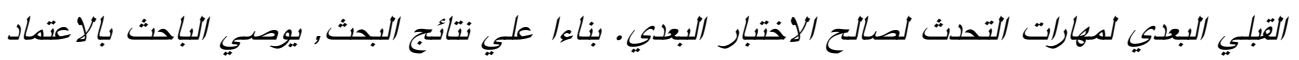

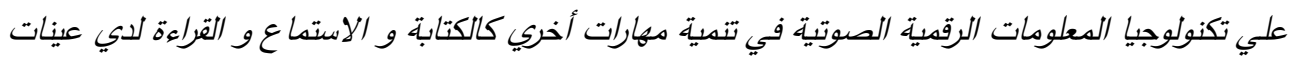

$$
\begin{aligned}
& \text { مختلفة. } \\
& \text { كلمات البجث: تكنولوجيا المعلومات الرقمية الصوتية, مهارات التحدث, الطلاب الدعلمين }
\end{aligned}
$$

\section{Introduction}

Teachers are considered the cornerstone of the educational process. Without qualified teachers who receive adequate qualities and skills, learning outcomes will not be satisfied. Today, student teachers should acquire many academic skills to qualify them for their future careers.

For many years, teaching EFL in Egyptian schools relied on the teacher-centred method. This method encouraged students' dependency, 
lack of motivation, and lack of creativity. It also minimized students' selflearning, and participation in activities. Students depended only on memorizing and recalling information for passing the exams (Salem, 2007; Ahmad, 2010).

In this teaching environment, learners do not find real opportunities to practice English or engage in authentic activities which encouraged them to search for other resources that help them to listen to native speakers and practice real communication in authentic situations (Abdallah, 2011).

Ahmed (2010) suggested that academic, culture and pedagogic preparation programs may help in preparing student teachers to conduct academic skills. He also added that student teachers' preparation programs should provide them with essential skills and qualifications that help them to be effective teachers.

Speaking skills are considered the most important skill among other skills. Every learner seeks to conduct speaking skills (Khamkhien, 2010). Learners feel frustrated when they cannot speak fluently although they have spent years trying to learn English (Rodríguez, 2012). Hadfield and Hadfield (2008) stated that EFL speakers' lack of interaction inside the classrooms affects their confidence in speaking when they are in a real situation.

Teaching EFL speaking skills have been taught through repeating and memorizing for several years but these methods proved that they cannot improve learners' skills. Speaking skills can be developed when you put learners in real life and authentic situations, encourage them to communicate, and help them to interact with one another (Thornbury, 2005).

DAISY is one of the modern technology that help users to listen to native language and help them to practice English in a useful and easy manner.

The main goal for DAISY technology is to enhance listening and reading experience. First DAISY player was based on audio only, however DAISY now compline between audio and written text and sometimes images. Now, DAISY can offer a wide range of free books for learners to

listen and read at the same time (Leas, Persoon, Soiffer \& Zacherle, 2008).

\section{Pilot Study}

The researcher conducted a pilot study to assess students' current level in EFL speaking skills. The researcher selected a random group of thirty one third year students at Faculty of Education, Port Said University. Speaking test measures pronunciation, fluency and lexical resource. 
Table (1): Results of the speaking test of the pilot study

\begin{tabular}{|c|c|c|c|c|c|c|}
\hline \multirow{2}{*}{ Speaking skill } & \multirow{2}{*}{ Total score } & Max. & Min. & $\begin{array}{c}\text { Mean } \\
\text { score }\end{array}$ & SD & percentage \\
\cline { 3 - 4 } & & score & score & & \\
\hline Pronunciation & 9 & 7 & 2 & 4.5 & 1.8 & $16.80 \%$ \\
\hline Fluency & 9 & 7 & 1 & 4.03 & 1.9 & $14.90 \%$ \\
\hline Lexical resource & 9 & 8 & 3 & 5.16 & 1.5 & $19.10 \%$ \\
\hline Total & $\mathbf{2 7}$ & $\mathbf{2 2}$ & $\mathbf{6}$ & $\mathbf{1 3 . 6 9}$ & $\mathbf{5 . 2}$ & $\mathbf{5 0 . 8 0 \%}$ \\
\hline
\end{tabular}

Results of the pilot study revealed that the percentage of the students' score in speaking test is $50.80 \%$. According to the mastery level indicators, student teachers must reach at least $85 \%$ and above. The percentage of the students' scores in EFL speaking skills test means that students of the English Department at the Faculty of Education, Port Said University need more improvement to enhance their speaking skills.

\section{Statement of the problem}

In light of the previous studies, literature review, and the pilot study results, the problem of the study can be stated as follows:

Third-year Faculty of Education, Port Said University students seemed to face problems in mastering EFL speaking skills. The low level of EFL speaking skills may be due to the traditional approaches of teaching these skills. Therefore, the current research suggested investigating the effect of using DAISY technology in enhancing EFL speaking skills.

\section{Questions of the study}

The current research attempted to answer the following question:

What is the effectiveness of a program based on DAISY technology in enhancing EFL speaking skills of EFL student teachers?

This question was divided into the following sub-questions:

1- What are the speaking sub-skills necessary for EFL student teachers?

2- What are the features of a program based on DAISY technology in enhancing speaking skills of EFL student teachers?

3- What is the effectiveness of a program based on DAISY technology in enhancing EFL student teachers' speaking skills?

\section{Purpose of the study}

The current study aimed to:

1- Identify the most needed speaking skills for EFL future teachers.

2- Develop a program based on DAISY technology to enhance EFL speaking skills of the third-year students at the Faculty of Education, Port Said University.

3- Investigate the effect of using DAISY technology in enhancing student teachers' speaking skills. 


\section{Significance of the study}

The current study may contribute to improving EFL speaking skills of students at the Faculty of Education, Port Said University through using DAISY technology. It also raises the awareness of the EFL university staff to the importance of using DAISY technology to teach these skills.

\section{Definition of terms:}

\section{DAISY (Digital Audio-Based Information SYstem)}

"DAISY standard is widely recognized as the ideal approach to providing navigable and accessible information. The acronym DAISY is often used to refer to a standard for producing accessible and navigable multimedia documents. In current practice, these documents are digital talking books, digital textbooks, or a combination of synchronized audio and text books". (Tank, Frederiksen, 2007).

DAISY can be operationally defined as a technology which uses a combination of sound and text synchronized together to enable readers to listen and read at the same time in order to develop speaking skills.

\section{Speaking}

Operationally, speaking skill can be defined as the performance of the student teacher which reflects the accuracy of using words, sentence and syntax in his speech, which enables him to express himself clearly and achieve interaction and effective communication with others.

\section{Literature Review \\ EFL Speaking Skills}

Speaking skills are considered the measurement for mastering the language they are also considered a pointer of the speaker capability of communication. Although speaking skills are essential when communicating in English, students find these skills are difficult to conduct. Understanding grammar and memorizing vocabulary don't qualify learners to speak appropriately. Mastering speaking, overcome fear, possess speaking sub-skills, self-confidence and mastering speaking elements are tools for perfect communication.

Regarding the same point, Hossain (2015) claimed that evaluating the success of EFL learning depends on how learners' capability of speaking. Fluency in speaking is the measurement of English language command. Penny (2000) added, speaking is the most important skill of the other skills. People who have command of the language are known as speakers of the language in a reference to the importance of speaking. Also Hossain (2015) added that students who master speaking skill has a better opportunity for further education and will be qualified for a better job because most 
companies and establishments seek an employee who can speak English fluently.

\section{Challenges in Teaching Speaking Skills}

Speaking is considered the most important skill among the four skills. EFL learners feel frustration when they fail to speak fluently despite the fact that they study English for many years. The most difficult part in speaking lies on the interaction between speakers (Rodríguez, 2012). Another difficulty is that speaker uses not only words but other elements to help him conveying the message. Speaker varies intonation and stress to clarify importance, emotions, attitude and even interest. Speaker may also rephrase what has been said and speed up or slow down, use body language and gestures, so listener has to interpret not only the message but the other elements to create a successful interaction (Harmer, 2008).

This situation is different when we mention speaking in L1. Speaking in L1 relies on some mechanisms to deliver the message such as using idioms, using simple sentences, omitting or adding explanation and using examples which gives the speaker fluency and decrease the hesitation and make easier communication (McLaren, Madrid \& Bueno, 2005). Speaking is not a planned or organized skill unless if we prepare for a speech or a presentation. Speaking is spontaneous, full of pauses, incomplete sentences, fillers, repetition and hesitations (Rodríguez, 2012).

\section{DAISY Technology}

DAISY is a framework to produce, store, record and play and read digital books. DAISY book includes text file (xml, html), image file and sound file (Mp3 or wav) (DAISY Consortium, 2007). DAISY books can be read through CDs, DVDs or internet applications on computers or smart phones (Spooner, 2014).

In addition to the files included in DAISY, it contains synchronization files which allow free navigation through the book bringing a similar experience to the printed books. Readers are able to navigate the whole book, move to the desired part, specific page or even word. Reader can also skip to the index and go back to the text, use bookmark, create comments, use dictionary and even listen to specific word, look up a ward in a dictionary and also search for a text. Users have the opportunity to access DAISY from several devices; DAIASY players, computers, smart phones, tablets, IPad, etc (Spooner, 2014).

Tank and Frederiksen (2007) added that when talking books were originally developed, readers were interviewed. Readers' comments were about that analogue recordings did not meet their expectations and did not 
motivate them to read. Poor access to certain points and poor sound system quality annoyed them which help in the new innovation of DAISY books to solve these problems.

\section{DAISY Components}

Components of DAISY have changed from audio files only to many components and are expected to have other richer components in the future.

Tank and Frederiksen (2007) mentioned that DAISY book is a multimedia format of a print book. A human voice recording is provided and synchronized to the text. Users can easily navigate through headings, chapters, pages and even words. Images may be added with their descriptions to some books. Users may also add bookmarks.

DAISY Consortium (2007) summarized DAISY components. It contains: 1) image files, audio files such as WAVE, MPEG-1, MPEG-2 or MP3, 2) the text file in (XML) format, 3) standard of DAISY Consortium, 4) the synchronization files (SMIL) format which parallel the text files, 5) the navigation control files (XML), 6) application files (NCX) which allows navigating to a specific point of the file which is linked to certain location of the audio and text files. DAISY DTBs books are not obliged to contain all these components.

In the near future, DAISY may contain -besides the mentioned components- video files. It will be full multimedia files which will help all learners and readers to enjoy learning (DAISY Consortium, 2007).

Tank and Frederiksen (2007) summarized six categories of DAISY types as follows:

1. Full audio files with titles only: a type without navigation. The content is presented as linear audio files only.

2. Full audio with only (NCC and NCX) navigation: navigation is sequential and hierarchical. In this type, DAISY represents the table of content of the print resource.

3. Full audio, partial text and full navigation: this type is similar to the previous one with some additional text. Additional text occurs when users search for a keyword in the index or glossary.

4. Full audio with full text: this type contains full text and full audio files. The two files are synchronized.

5. Full text with some audio: a complete text and limited audio files are provided. This type may be used in dictionary. Also the audio and text files are connected.

6. Full text and no audio: it contains electronic text only. There is no audio file added. 


\section{Previous Studies}

Some previous studies related to using DAISY technology in education were reviewed.

Lundeland (2006) focused on using DAISY with special needs learners. Six students of secondary schools and their teachers were interviewed. The study focused on use technical issues, many types of books, learners' motivation and user training courses. Results revealed the importance of using DAISY as an educational tool to overcome learning difficulties of learners with special needs.

Montgomery (2009) investigated the factors affecting reading level and its impact on academic performance of English language learners and native English speakers of middle school students. The researcher used audio books as suggested approach to improve reading comprehension level. The result of this research approved that using audio books can improve reading and academic performance of students at middle level schools.

In their study, Esteves and Whitten (2011) compared the effectiveness of reading with audiobooks comparing with traditional practice of reading and its effect on reading fluency and attitude toward reading of upper elementary school students with reading disabilities. Students exposed to read authentic materials five times a week. Descriptive statistics and t-tests were used to compare the differences of the participants of each group Results of the study approved that using audiobooks affects reading fluency of the experimental. There were no significance differences in the reading attitude.

Lundh and Johnson (2015) studied the using of DAISY books with print disabilities readers. Twelve empirical studies were conducted. The research focused on using of talking books and social settings where talking books are used. Findings of the study revealed that navigational features of DAISY provide new approaches to reading. Also the results depended on the why and how DAISY is used.

Hung and Young, (2015) used e-reader to facilitate EFL academic writing process. Data were collected and analyzed to study students' academic writing performance with and without e-reader. Results revealed that e-readers can be a successful tool in developing academic writing. Moreover, e-reader is benefit in writing process and create better writing environment.

Previous studies revealed the significance of using DAISY technology in teaching English language in general and EFL in particular. DAISY is 
mainly used in developing reading but according to its features especially the synchronization between sound and text, researcher found that it might be useful to use DAISY to enhance productive skills. In DAISY technology, text (reading) and sound (listening) represent the receptive skills as mentioned before, receptive skills are considered input and productive skills are considered output of the learning process. Research focuses on using DAISY as a tool depends on receptive skills to enhance productive skills (speaking and writing).

\section{Hypotheses}

In order to answer the questions of the study, the following hypothesis was formulated:

There is a statistically significant difference at the 0.01 level between the mean score of the students in the pre and post-measurement of the EFL speaking test in favor of the post-measurement.

\section{Delimitations}

The present study is delimited to:

1- A group of the third year students at Faculty of Education, Port Said University.

2- Some speaking sub-skills needed for the students of Education, Port Said University.

3- A proposed program using DAISY technology.

\section{Methodology of the study}

The method of the current research includes the design, participants, and instrument and the procedures followed to carry out the study.

\section{Design}

The research adopts the one-group pre and post-test quasiexperimental design. The design of the research aimed at investigating the impact of using DAISY technology to enhance student teachers' speaking skills.

\section{Participants}

The sample of the research included (34) third-year students of Faculty of Education, Port Said University who voluntarily participated in the program. The sample included general and primary English major students.

\section{Instruments}

To test the hypotheses of the research and the impact of DAISY program on the participants, the researcher developed and used the following instruments:

1. EFL Speaking Skills Checklist. 
2. EFL Pre-Post Speaking Test.

3. Speaking Scoring Rubric.

\section{Description of the Instrument}

\section{Speaking Skills Checklist}

The researcher reviewed the related literature in order to identify the most important speaking sub-skills and micro-skills that are needed for EFL student teachers. A list of initial speaking skills was represented to (jury committee of curricula and instruction, Methods of Teaching English as a Foreign Language) to determine the most relevant skills.

After taking the jury's comments and feedback into consideration, the researcher modified the list in order to build the final form. The final form of speaking skills checklist consisted of six sub-skills. Each sub-skill included three micro-skills of total (18) micro-skills.

\section{EFL Pre and Post-Speaking Tests}

The researcher designed EFL pre-post speaking tests. The speaking pre-test was designed to measure students' speaking level before participating in the program. Speaking post-test was designed to measure students' speaking skills after using DAISY technology program. The posttest determined the importance of using the proposed program in enhancing the EFL speaking skills of the study group.

Speaking pre and post-tests consists of three parts. In Part one, the examiner asks the candidate some simple personal questions of everyday familiar topics. In Part two, the examiner gives the candidate some cards each card contains a topic or a picture. The candidate has to choose one card to talk about the topic or describe the picture. In the third part, examiner engages the candidate in a short discussion. The candidate is asked to do more complicated skills, such as evaluate, justify positions and opinions, make predictions, and express preferences.

\section{The validity of the Speaking Tests}

The test validity was established through different stages as shown below:

\section{A. Content Validity:}

To measure the content validity of pre and post-speaking tests, it was submitted to an EFL jury committee in order to determine the suitability of the test items to the final check list and appropriateness of the test questions to the students' level. According to their suggestions and comments, tests were modified.

\section{B. Construct Validity}

To examine the validity of the test construction, it was administered to a random sample of (49) third year EFL students at Faculty of Education; 
Port Said University then Pearson correlation coefficient was calculated as illustrated below:

Table (2): Establishing the EFL Pre-Post Speaking Skills Test Construct Validity

\begin{tabular}{|c|c|}
\hline Skills & Correlation coefficient \\
\hline Pronunciation & $0.945^{* *}$ \\
\hline Fluency & $0.925^{* *}$ \\
\hline Vocabulary & $0.441^{* *}$ \\
\hline Grammar & $0.920^{* *}$ \\
\hline Content & $0.925^{* *}$ \\
\hline Pragmatics & $0.903^{* *}$ \\
\hline$* *$ Correlation is significant at the 0.01
\end{tabular}

Results in table (2) report a statistically significant correlation at the 0.01 level between the speaking sub-skills and the total test score. These correlations were $0.94,0.92,0.44,0.92,0.92$ and 0.90 respectively.

From the above description, it is proved that correlation coefficient between the test items is positive and statistically significant at 0.01 level which indicates the validity of the test structure and proved the validity of the test construction to measure speaking skills.

\section{Discriminant Validity}

To calculate the validity of the items of the tests, the researcher administrated the tests to a sample of (49) students. t-test was used to measure discrimination index. Results are shown in table (3):

Table (3): Establishing the EFL Pre-Post Speaking Skills Test Discriminant Validity

\begin{tabular}{|c|c|c|c|c|c|c|}
\hline Group & $\mathbf{N}$ & Mean & $\begin{array}{c}\text { Std. } \\
\text { Deviation }\end{array}$ & Df & t- value & sig \\
\hline the upper group of speaking test & 13 & 18.54 & 3.59 & 24 & 12.348 & 0.01 \\
\hline the lower group of speaking test & 13 & 6.15 & 0.375 & & & \\
\hline
\end{tabular}

Results are shown in the above table proved that there are statistically significant differences between mean scores of the upper group and lower group in speaking test at the (0.01) level which indicates that the test differentiates between the highest and lowest students' speaking level which proved the validity of the test.

\section{Reliability of the Speaking Test}

To calculate the reliability of the EFL speaking pre-posttests, Cronbach's Alpha coefficient was used. The researcher administrated the tests to a sample of (49) students. The reliability coefficient was (0.918) which illustrate that the tests are highly reliable.

\section{Speaking Scoring Rubric}

The researcher designed a speaking rubric according to the final form of the speaking skills checklist to evaluate student teachers' level of 
speaking performance. The rubric was developed to evaluate the six subskills of the main skill. It consisted of five dimensions: excellent, very good, good, acceptable and failed. The highest score is thirty points and the lowest score is six.

To determine the validity of the rubric, the initial form was presented to an EFL jury committee. In the light of their comments and suggestions, some items were modified or rephrased and some items were deleted to reach the final form of the rubric.

\section{DAISY Program}

The following part is concerned with describing the procedures of designing and implementing the program and applying it.

\section{Main Objective of the Program}

The program is mainly designed to enhance student teachers' speaking skills. The program intended to develop six sub-skills according to the speaking skills checklist.

\section{Stages of Designing the Program}

To design a program based on DAISY technology to enhance speaking skills, the researcher adopted the following phases: study and analysis, design, using DAISY program and evaluation.

1) Study and analysis

The researcher conducted a pilot study to evaluate the participants' level of speaking skills. The results of the pilot study were not satisfied as the participants were studying EFL for two years and the major study was English.

Moreover, literature review and previous studies indicated that it was obviously clear that teaching English with modern methods and technology was very useful in achieving high standards. Also, engaging students in hands-on activities help them in enhancing their abilities and raising their motivation to learn.

2) Design

The procedures for designing the program are explained as follows:

- Setting the Goals

The main goal of the program is to enhance EFL student teachers' speaking skills. After reviewing the literature and related studies, the researcher defined six sub-skills and then defined three micro-skills under each sub-skill. According to the main skills, sub-skills and micro-skills, the outline and objectives of the program were developed.

- Choosing the Content of the Program

After an open discussion with the participants, they chose (Oliver 
Twist) novel as the content of the program.

- Organizing the Activities

The researcher used speaking activities such as discussion, role play, interview, listening and recording, self and pair assessment and pair and group work.

Participants were asked to read about the skills in order to join the discussion in the next lecture. The researcher provided the participants with some internet sites to help them in their reading. After the discussion, the researcher engaged the participants in activities to help them develop their skills.

3) Using DAISY Program

Participants also can use a smartphone or computer. In smartphones, they can download any application from the free applications store. Participants who don't have smartphones or couldn't download the target applications could use computers and download free programs. The researcher provided them with some of these apps and programs.

Participants who have smartphones and android can download these apps: Text to speech

- Pdf voice text

- Voice out

- Text voice free

- Go read

- Pdf audio reader

- Pdf reader

- Pdf to voice

- @voice

4) Evaluation

To evaluate the participants, the researcher followed the summative and formative evaluation. The researcher recorded every activity and asked the participants to send the records they made so that the researcher could evaluate the participants' progress. Regarding the assessment during the application, the researcher conducted self-assessment, pair assessment, group assessment and observation.

\section{Findings}

Testing the Hypotheses

The hypothesis of the research stated that "there is a statistically significant difference at the 0.01 level between the mean score of the students in the pre and post measurement of the EFL speaking skills test in favor of the post-measurement." To test the hypothesis, the t-test was used 
to compare the students' total mean scores on the pre and post-test. Results of testing the first hypothesis are illustrated in the following table:

Table (4): Comparing the mean score of the students in the pre and post measurement of the EFL speaking skills test.

\begin{tabular}{|c|c|c|c|c|c|}
\hline Skills & Test & Mean & S. D & DF & t-Value \\
\hline Pronunciation & Pre-test & 1.85 & 0.93 & 33 & $11.84^{*}$ \\
& Post-test & 2.85 & 1.02 & & \\
\hline Fluency & Pre-test & 1.76 & 0.92 & 33 & $12.63^{*}$ \\
& Post-test & 2.82 & 0.97 & & $10.36^{*}$ \\
\hline Vocabulary & Pre-test & 2.03 & 0.99 & 33 & $8.92^{*}$ \\
& Post-test & 2.79 & 0.98 & & $9.23^{*}$ \\
\hline Grammar & Pre-test & 2 & 0.95 & 33 & $5.75^{*}$ \\
& Post-test & 2.85 & 0.86 & & \\
\hline Content & Pre-test & 1.71 & 0.87 & 33 & $22.78^{*}$ \\
\hline Pragmatics & Post-test & 2.53 & 0.87 & & \\
& Pre-test & 1.56 & 0.74 & 33 & \\
\hline Total & Post-test & 2.06 & 0.78 & & \\
& Pre-test & 10.91 & 5.05 & 33 & \\
& Post-test & 15.91 & 4.74 & & \\
\hline
\end{tabular}

* Significant at the 0.01 level

Results in table (4) reveal that student's performance on the post administration of the EFL speaking skills test was significantly better than their performance in the pre-administration of the test $(t=22.8)$. The study group students' performance on the post-test proved to be considerably better than the pre-test in all target sub-skills $(\mathrm{t}=11.8,12.6,10.3,8.9,9.2$ and 5.7 respectively).

\section{Conclusion}

Results illustrated above reveal the statistically significant difference between the mean scores of the study group in the pre-post administration in favor of the post-administration which indicates the improvement of the study group of the speaking skills.

Moreover, the results also agreed with other researches such as Lundeland (2006); Montgomery (2009); Esteves and Whitten (2011); Lundh and Johnson (2015); and Hung and Young, (2015) which proved the impact of using DAISY technology in improving English language skills.

The improvement of the study group may be due to the effect of using the suggested program based on DAISY technology. Also, the results might be attributed to the activities which were included in the suggested program which encouraged and motivated the participants to interact and communicate using the focused skills. 


\section{References}

Abdallah, M. M. (2011). Teaching English as a Foreign Language from a New Literacy Perspective. Assiut University College of Education, Egypt. Ahmed, A. H. M. A. H. (2010). The EFL essay writing difficulties of Egyptian student teachers of English: implications for essay writing curriculum and instruction (Doctoral dissertation, University of Exeter).

Daisy Consortium. (2007). Daisy tools.

Esteves, K. J., \& Whitten, E. (2011). Assisted reading with digital audiobooks for students with reading disabilities. Reading Horizons, $51(1)$,

Hadfield, J., \& Hadfield, C. (2008). Introduction to teaching English. Oxford university press.

Harmer, J. (2008). How to teach English. ELT journal, 62(3), 313-316.

Hossain, M. I. (2015). Teaching productive skills to the students: a secondary level scenario (Doctoral dissertation, BRAC University).

Hung, H. C., \& Young, S. S. C. (2015). The effectiveness of adopting Ereaders to facilitate EFL students' process-based academic writing. Journal of Educational Technology \& Society, 18(1), 250-263.

Khamkhien, A. (2010). Teaching English Speaking and English Speaking Tests in the Thai Context: A Reflection from Thai Perspective. English Language Teaching, 3(1), 184-190.

Leas, D., Persoon, E., Soiffer, N., \& Zacherle, M. (2008). Daisy 3: A standard for accessible multimedia books. IEEE MultiMedia, 15(4), 28-37.

Lundeland, N. (2006). When the book is hard to digest: DAISY books, digital aids for students with reading difficulties. (Master's thesis), Oslo University.

Lundh, A., \& Johnson, G. (2015). The use of digital talking books by people with print disabilities: A literature review. Library Hi Tech, 33(1), 54-64.

McLaren, N., Madrid, D. Y., \& Bueno, A. (2005). TEFL in Secondary Education. Granada: Editorial Universidad de Granada.

Montgomery, J. R. (2009). Using Audio Books to Improve Reading and Academic Performance. Online Submission. ERIC, ED505947.

Penny, U. (2000). A course in language teaching: Practice and theory. Cambridge: Cambridge University.

Rodríguez, M. R. (2012). The Importance of Teaching Listening and Speaking Skills. Segura Alonso. Rocio Convocatoria de Junio. 
Salem, M. S. A. S. (2007). The effect of journal writing on written performance, writing apprehension, and attitudes of Egyptian English majors.

Spooner, S. (2014). "What page, Miss?" Enhancing Text Accessibility with DAISY (Digital Accessible Information SYstem). Journal of Visual Impairment \& Blindness, 108(3), 201-211.

Tank, E., \& Frederiksen, C. (2007). The DAISY standard: entering the global virtual library. Library trends, 55(4), 932-949.

Thornbury, S. (2005). How to teach speaking. Longman. 